\author{
원주지역 남은 음식물의 계절별 성분 함량 및 비육돈에 대한 \\ 건조 남은 음식물 급여 효과 \\ 채병조*.주지환*심영호*권일경*.김상헌** \\ 강원대학교 동물자원과학대학*, 농업생명과학대학**
}

\title{
Seasonal Variations in Chemical Composition of Dried Food Waste in Wonjusi and Its Feeding Effects in Finishing Pigs
}

\author{
B. J. Chae*, J. H. Joo*, Y. H. Shim*, I. K. Kwon*, S. H. Kim** \\ College of Animal Resources Sciences, Kangwon National University*, \\ and Agriculture and Life Science, Kangwon National University**
}

\begin{abstract}
A study was conducted to evaluate seasonal variations in chemical composition of food waste (FW) and its feeding effects on growth performance and pork quality in finishing pigs. FW was collected for 1 year (6 times a month) to establish a database for use of FW as a feed ingredient. For a feeding trial ( 8 weeks), a total of 117 pigs $(\mathrm{L} \times \mathrm{Y} \times \mathrm{D} ; 54.80 \pm 4.60 \mathrm{~kg})$ were used to evaluate the processing effects of FW. Treatments were: Control (a corn-soybean meal diet without FW), simple dried FW (SD) and vacuum fermented FW (VF). The gross energy, crude protein, crude fat, ash, calcium and phosphorus in FW (DM, average of 4 seasons) were $5,111 \mathrm{kcal} / \mathrm{kg}, 22.92 \%, 14.31 \%, 15.48 \%, 2.7 \%$ and $1.05 \%$, respectively. Among seasons, the energy and crude protein contents were the highest $(\mathrm{p}<0.05)$ in winter and summer, respectively. In lactic acid bacterial counts, there was no difference between SD and VF. Pigs fed the control diet grew faster $(p<0.05)$ than those fed diets containing food wastes, but not feed conversion ratio. There were no differences in production traits between SD and VF. No differences were also found in dressing percentage, backfat thickness, and pork quality (color, drip loss and TBARS) among treatments. The feed cost (W/kg body weight) was lower in pigs fed FW than those fed a control diet. In conclusion, a pelleted diet containing food waste less than $20 \%$ would reduce feed cost in finishing pigs. However, it seems that a vacuum fermentation of food waste is not necessary for diet processing.
\end{abstract}

(Key words : Dried, Vacuum fermented food waste, Growth, Pork quality, Pig)

$\begin{array}{cl}\text { I . 서 론 } & \text { 속적으로 강구되고 있다 (Westendorf 등, 1996; } \\ & \text { Bryhni 등, 1999; 이 등, 2001). 우리나라에서도 } \\ \text { 환경오염에 따른 남은 음식물의 처리가 어려 } & \text { 지난 1997년 경제적인 곤란 (IMF)을 겪게 되자 } \\ \text { 워짐에 따라 이를 사료로 이용하는 방안이 지 } & \text { 많은 농가에서 남은 음식물을 사료화하기 시작 }\end{array}$

Corresponding author : B. J. Chae, College of Animal Resource Sciences, Kangwon National University. Tel: 033) 250-8616. E-mail: bjchae@kangwon.ac.kr 
하였으며, 반추동물이 아닌 농장에서는 지금도 일부 사료로 이용하고 있다.

남은 음식물을 사료화하는데 있어서 큰 문제 점으로서는 남은 음식물 그 자체가 수거장소나 시기에 따라 성분이 일정하지 못하다는 점과 (이, 1998; Chae 등, 2000) 급여하기까지 어떠 한 가공 (처리)공정을 거치느냐에 따라 사료가 치와 비용이 달라진다는 것이다 (유, 2001).

남은 음식물을 사료화하는 방법은 건식과 습 식이 있으며, 발효과정을 거칠 수도 있다. 남은 음식물을 발효시킬 경우, 유해균을 사멸하고 유익균의 증식을 유도할 뿐만 아니라 사료중의 악취를 저감시킴으로서 사료가치를 향상시키게 되는 장점도 있다 (오, 2001).

일반적으로 건식은 습식에 비해 처리비용이 높다. 유 (2001)의 자료에 의하면 1 톤당 처리비 용이 건식사료는 65,639 원, 습식사료는 33,464 원이다. 그러나 습식사료를 돼지에게 급여할 경우 사료섭취량이 많아 분뇨 배설량이 늘어나 게 되는 문제점도 있다(문, 2001). 건식사료의 경우 육성비육돈에서 가루사료로 사료 중 $20 \%$ 를 첨가하면 돼지의 성장에는 별 문제가 없는 것으로 나타났으나(Chae 등, 2000) 먼지 발생량 이 많은 문제점이 제기되었다. 펠렛가공할 경 우 이런 문제를 해결할 수 있는데, 이 등 (2001)은 비육돈에서 건조한 남은 음식물은 $10 \%$ 첨가가 적당하다고 보고했는데 사료 중 $10 \%$ 를 사용하는 것은 사용량이 너무 적은 편 이기도 하다.

따라서 본 연구에서는 남은 음식물을 사료화 하는데 있어서 기본 자료가 부족하기 때문에 이러한 자료를 확보하기 위해 강원도 원주시에 서 수거한 남은 음식물 시료를 1년간 분석하였 으며, 사료화 방법중에서 건식이 습식보다는 합리적인 것으로 판단되어 건조처리를 함과 동 시에 건조 후 발효처리를 하여 이것이 비육돈 에서 성장과 육질에 어떠한 영향을 미치는지를 조사하였다.

\section{ㅍ. 재료 및 방법}

\section{1. 남은 음식물의 수집 및 처리}

강원도 원주시에서 남은 음식물 (food waste: $\mathrm{FW}$ )의 성분을 조사하여 사료화하는데 기초자 료로 활용하고져 2001년 3월부터 2002년 2월까 지 월 6회 수집하여 조사하였다. 수집된 FW내 이물질을 제거한 후 분쇄하여 5톤 단위에서 여 러 번 (5 6회) 시료를 채취한 후 혼합하여 하나 의 시료로 활용하였다.

사양시험을 위해 별도로 수집된 $\mathrm{FW}$ 를 파쇄 한 후 스크류식 탈수기를 이용하여 1차 수분 함량이 $70 \%$ 정도가 되도록 한 후, 열풍식건조 기 (킬른건조기, 영원기계)를 이용하여 $130 \pm 10$ ${ }^{\circ} \mathrm{C}$ 에서 수분이 $40 \sim 50 \%$ 가 될 때까지 (1시간) 건조하여 시험설계에 따라 활용하였다.

\section{2. 공시 동물, 시험설계 및 시험사료}

삼원교잡종 $(\mathrm{L} \times \mathrm{Y} \times \mathrm{D}) \quad$ 비육돈 $($ 개시체중 54.80 $\pm 4.60 \mathrm{~kg}$ ) 117 두를 공시하여 비육전기 (4주)와 비육후기 (4주), 총 8 주간 사양시험을 실시하였 다. 처리는 대조구(일반배합사료), 건조 방법에 따른 단순 건조(simple dry: $\mathrm{SD}$ ), 진공발효 (vacuum fermentation: VF) 등 3 처리로 구분하 였다. 처리별 3 반복으로 반복당 13 두 (암 6 , 수 7)씩 배치하여 바닥이 반스랏형인 돈사 $(3.5 \mathrm{~m} \times 3.0 \mathrm{~m})$ 에서 사육하였다.

Table 1에서 보는바와 같이 비육전기의 시험 사료로 대사에너지 $3,300 \mathrm{kcal} / \mathrm{kg}$, 단백질 16.50 $\%$, 라이신 $0.95 \%$ 가 되도록 배합하였고, 비육후 기의 시험사료는 대사에너지 $3,200 \mathrm{kcal} / \mathrm{kg}$, 단백 질 $14.50 \%$, 라이신 $0.75 \%$ 이상이 되도록 배합 하였다. 시험사료의 생산은 대조구는 시판 배 합사료 형태의 옥수수-대두박 위주의 사료를 $80 \pm 5^{\circ} \mathrm{C}$ 에서 150 마력의 펠렛기를 이용하여 성 형하였다. $\mathrm{SD}$ 처리구의 사료는 킬른건조기에서 수분이 $40 \% \sim 50 \%$ 상태에서 수분 $15 \%$ 로 환산 
Table 1. Formula and chemical composition of experimental diets for feeding trials

\begin{tabular}{|c|c|c|c|c|}
\hline \multirow{2}{*}{ Ingredients (\%) } & \multicolumn{2}{|c|}{ Phase I } & \multicolumn{2}{|c|}{ Phase II } \\
\hline & Control & Food waste & Control & Food waste \\
\hline Corn & 65.56 & 53.94 & 69.69 & 51.21 \\
\hline Food waste & - & 20.00 & - & 20.00 \\
\hline SBM (44\%) & 23.60 & 16.10 & 16.60 & 11.75 \\
\hline Wheat bran & 5.00 & 5.00 & 10.00 & 13.00 \\
\hline Animal fat & 2.60 & 3.40 & 1.00 & 3.00 \\
\hline Limestone & 1.25 & - & 1.15 & - \\
\hline $\mathrm{DCP}$ & 1.20 & 0.90 & 0.86 & 0.50 \\
\hline Salt & 0.30 & - & 0.30 & - \\
\hline Mineral premix ${ }^{1)}$ & 0.20 & 0.20 & 0.20 & 0.20 \\
\hline Vitamin premix $^{2)}$ & 0.10 & 0.10 & 0.10 & 0.10 \\
\hline Lysine & 0.10 & 0.27 & 0.06 & 0.20 \\
\hline CTC & 0.05 & 0.05 & - & - \\
\hline Choline chloride $(25 \%)$ & 0.04 & 0.04 & 0.04 & 0.04 \\
\hline Total & 100.00 & 100.00 & 100.00 & 100.00 \\
\hline \multicolumn{5}{|l|}{ Chemical composition $(\%)$} \\
\hline $\mathrm{ME}(\mathrm{kcal} / \mathrm{kg})$ & 3,300 & 3,300 & 3,200 & 3,200 \\
\hline $\mathrm{CP}$ & 16.50 & 16.60 & 14.50 & 15.50 \\
\hline $\mathrm{Ca}$ & 0.80 & 0.80 & 0.68 & 0.80 \\
\hline Av-P & 0.30 & 0.30 & 0.25 & 0.25 \\
\hline Lys & 0.95 & 0.95 & 0.75 & 0.75 \\
\hline Met + Cys & 0.57 & 0.57 & 0.53 & 0.54 \\
\hline
\end{tabular}

1) Supplied per kg diet : 200mg Cu, 100mg Fe, 150mg Zn, 60mg Mn, 1mg I, 0.5mg Co, 0.3mg Se.

2) Supplied per $\mathrm{kg}$ diet : 8,000IU vitamin $\mathrm{A}, 2,500 \mathrm{IU}$ vitamin $\mathrm{D}_{3}$, 30IU vitamin $\mathrm{E}$, 3mg vitamin $\mathrm{K}, 1.5 \mathrm{mg}$ thiamin, $10 \mathrm{mg}$ riboflavin, $2 \mathrm{mg}$ vitamin $\mathrm{B}_{6}, 40 \mathrm{~g}$ vitamin $\mathrm{B}_{12}, 30 \mathrm{mg}$ pantothenic acid, $60 \mathrm{mg}$ niacine, $0.1 \mathrm{mg}$ biotin, $0.5 \mathrm{mg}$ folic acid.

한 후 Table 1의 배합비로 혼합한 후 펠렛기로 성형시켰다. $\mathrm{VF}$ 사료는 $\mathrm{FW}$ 를 $\mathrm{SD}$ 처리 후 다른 원료와 혼합한 다음 펠렛성형하기 전에 진공발 효기(신영기계)에서 $60 \sim 70^{\circ} \mathrm{C}$ 로 2시간 발효 (수 분 $19 \%$ 상태)시킨 후 펠렛기로 성형시켰다.

\section{3. 경제성 분석}

일반 건조사료와 진공발효사료 제조시 건조
및 발효를 위해 소요된 유류 비용과 전기비용 을 산출하였다. 시험 생산중 사용된 유류비는 460 원/ $\ell$ 이였으며, 전기는 산업용 전기(갑)를 적용하여 산출하였으며, 기본사용료를 제외한 평균 비용은 55.4 원 $/ \mathrm{kwh}$ 였다.

실제 남은 음식물을 기준으로 산출된 톤당 가공비는 단순건조사료의 경우 26,132 원이었으 며, 진공발효사료의 경우는 28,399 원으로 나타 났다. 여기서 펠렛 성형에 소요된 가공비는 처 
리간에 유사하다고 판단되어 추가적으로 삽입 하지 않았다. 또한 시험사료에서 투입된 건조 음식물은 지자체에서 가공비로 지원해주기 때 문에 사료비에 산정하지 않았다.

\section{4. 사양관리 및 조사항목}

시험돈의 사양관리는 일반농장의 관행법에 준하여 실시하였다. 물과 사료는 자유채식토록 하였고 사료이외의 첨가제나 약품은 일체 사용 하지 않았다. 4주 간격으로 체중과 사료섭취량 을 측정하여 증체량, 사료섭취량 및 사료요구 율을 산출하였다. 영양소 소화율을 측정하기 위해 사양시험기간 중 시험사료에 $\mathrm{Cr}_{2} \mathrm{O}_{3}$ 을 $0.3 \%$ 첨가하였다. 그리고 분 채취는 지시제를 첨가한 사료를 5 일 급여 후에 각 돈방에서 채 취하였다. 분석을 위해 $60^{\circ} \mathrm{C}$ 열풍건조기에서 72시간 건조하였다.

사양실험 후 평균체중이 $101.01 \pm 4.68 \mathrm{~kg}$ 인 거 세돈 9두 (처리당 3 두)를 선택하여 도체성상을 평가하였다. 또한, 돈육샘플 (M. Longissimus $\mathrm{Dorsi}$ )을 취하여 육색과 마블링 지수 (NPPC, 1991)를 산출하였으며, 폴리에틸렌 비닐로 봉하 여 TBARS (thiobarbituric acid reactive substance)와 drip loss를 측정하기 위해 $2^{\circ} \mathrm{C}$ 냉장 고에서 보관하였다.

\section{5. 시료 및 통계분석}

사료와 분의 일반성분은 $\mathrm{AOAC}(1990)$ 방법에 의하여 실시하였으며, 총에너지는 Adiabatic Bomb Calorimeter (Model 1261, Parr Instrument Co., Molin, IL)를 사용하였다. Chromic oxide $\left(\mathrm{Cr}_{2} \mathrm{O}_{3}\right)$ 는 acid digestion method (한 등, 1987)에 의하여 spectrophotometer (Model V-550, Jasco Co., Japan)를 이용하여 $430 \mathrm{~nm}$ 에서 흡광도를 측정하여 chromic oxide 함량을 계산하였다. 아 미노산 함량은 24 시간 동안 $110^{\circ} \mathrm{C}$ 에서 $6 \mathrm{~N} \mathrm{HCl}$ 로 산가수분해 시킨 후 HPLC(Waters, 486)를
사용하여 측정하였다.

TBARS는 Sinnhuber와 $\mathrm{Yu}(1977)$ 의 방법을 약 간 수정하여 실시하였다. 시험관내에 세절육 $0.4 \mathrm{~g}$ 을 정확히 정량하여 항산화제 용액 (propylene glycol + warm Tween + BHT + BHA) 2 3 방울, TBA 용액 3ml, TCA-HCL $17 \mathrm{ml}$ 를 넣고 vortex에서 2 3초간 혼합하였다. 시험관 의 마개를 닫고 $100^{\circ} \mathrm{C}$ 이상의 물에서 30 분간 가열한 후에 냉각하였다. 마개를 열고 $5 \mathrm{ml}$ 의 반응액을 새 시험관에 옮기고 여기에 chloroform $2 \mathrm{ml}$ 를 넣은 다음 $3,000 \mathrm{rpm}$ 에서 15 분간 원 심분리시켜 상등액을 $532 \mathrm{~nm}$ 에서 흡광도를 측 정하였다. 최종 $\mathrm{TBARS}$ 의 계산은 시료 $\mathrm{kg}$ 당 반 응물 $\mathrm{mg}$ 으로 계산하였다.

TBARS (mg malonaldehyde/kg sample) =

$$
\frac{(\mathrm{As}-\mathrm{Ab}) \times 46}{\text { Sample }(\mathrm{g}) \times 5}
$$

As : Absorbance of sample

$\mathrm{Ab}$ : Absorbance of blank

Drip loss는 시료의 중량을 $100 \pm 4 \mathrm{~g}$ 되게 일 정한 모양으로 절단하여 polypropylene bag에 넣어 $2{ }^{\circ} \mathrm{C}$ 냉장고에 저장하여 5 일과 10 일 후에 발생한 감량을 시료중량에 대한 drip loss로 산 출하였다 (Kim 등, 1997).

미생물분석을 위해 시료는 $0.1 \%$ peptone 용 액으로 희석하였으며, 총균수 (total bacterial counts; TBC)는 standard plate count agar (Difco 제)에서 $32^{\circ} \mathrm{C} \quad 48$ 시간, 유산균수 (lactic acid bacterial counts: LAB)는 MRS agar (Difco 제) 에서 $32^{\circ} \mathrm{C} 48$ 시간, 그리고 대장균군 (coli form bacteria)은 violet red bile agar (Difco 제)를 사 용하여 $37^{\circ} \mathrm{C}$ 에서 24 시간 배양한 후 산정하였 다.

본 시험에서 얻어진 모든 자료는 $\mathrm{SAS}$ 프로그 램 (1985)을 이용하여 분산분석을 실시하였고 처리 평균간의 유의성 검정은 Duncan의 다중 
검정법 (Snedecor와 Cochran, 1980)을 이용하였 다.

\section{III. 결과 및 고찰}

1. 남은 음식물의 계절별 성분 함량과 발효 후 미생물 변화
$\mathrm{FW}$ 의 계절별 성분 함량은 Table 2와 같다. 건물기준으로 에너지, 조단백질, 조지방, 회분, 칼슘 및 인의 4계절 평균치는 각각 5,111 $\mathrm{kcal} / \mathrm{kg}, \quad 22.92 \%, \quad 14.31 \%, \quad 15.48 \%, \quad 2.7 \%$ 및 $1.05 \%$ 였다. 우선 에너지 함량을 살펴보면, 여름 과 가을이 겨울에 비해 유의적으로 낮았다 $(\mathrm{p}<0.05)$. 조단백질은 4 계절 중 여름이 가장 높

Table 2. Chemical composition of food waste by season ${ }^{1}$ (DM basis)

\begin{tabular}{|c|c|c|c|c|c|c|}
\hline & $\begin{array}{c}\text { Spring } \\
(3-5) \\
\end{array}$ & $\begin{array}{c}\text { Summer } \\
(6-8) \\
\end{array}$ & $\begin{array}{c}\text { Fall } \\
(9-11) \\
\end{array}$ & $\begin{array}{l}\text { Winter } \\
(12-2) \\
\end{array}$ & Mean & SE \\
\hline GE (kcal/kg) & $5,199.35^{\mathrm{ab}}$ & $4,903.95^{\mathrm{b}}$ & $4,955.93^{\mathrm{b}}$ & $5,384.78^{\mathrm{a}}$ & $5,111.00$ & 506.23 \\
\hline C. protein $(\%)$ & $22.94^{b}$ & $25.92^{\mathrm{a}}$ & $23.02^{b}$ & $19.80^{c}$ & 22.92 & 3.48 \\
\hline C. fat $(\%)$ & $17.21^{\mathrm{a}}$ & $15.54^{\mathrm{b}}$ & $11.25^{\mathrm{d}}$ & $13.24^{\mathrm{c}}$ & 14.31 & 3.25 \\
\hline C. ash $(\%)$ & $16.16^{\mathrm{a}}$ & $15.18^{\mathrm{ab}}$ & $16.39^{\mathrm{a}}$ & $14.21^{\mathrm{b}}$ & 15.48 & 2.32 \\
\hline $\mathrm{Ca}(\%)$ & $2.73^{\mathrm{b}}$ & $2.05^{\mathrm{b}}$ & $3.49^{\mathrm{a}}$ & $2.54^{\mathrm{b}}$ & 2.70 & 1.14 \\
\hline $\mathrm{P}(\%)$ & 0.97 & 1.15 & 1.00 & 1.06 & 1.05 & 0.32 \\
\hline \multicolumn{7}{|c|}{ Essential amino acids (\%) } \\
\hline Arg & $0.77^{\mathrm{b}}$ & $0.93^{\mathrm{b}}$ & $0.80^{\mathrm{b}}$ & $1.29^{\mathrm{a}}$ & 0.95 & 0.42 \\
\hline Lys & $0.49^{\mathrm{b}}$ & $0.41^{\mathrm{b}}$ & $0.69^{\mathrm{a}}$ & $0.79^{\mathrm{a}}$ & 0.59 & 0.28 \\
\hline His & $0.28^{\mathrm{c}}$ & $0.35^{\mathrm{bc}}$ & $0.59^{\mathrm{a}}$ & $0.40^{\mathrm{b}}$ & 0.40 & 0.19 \\
\hline Leu & $0.66^{\mathrm{b}}$ & $0.69^{\mathrm{b}}$ & $1.03^{\mathrm{a}}$ & $1.05^{\mathrm{a}}$ & 0.86 & 0.26 \\
\hline Ile & $0.49^{\mathrm{b}}$ & $0.40^{\mathrm{c}}$ & $0.58^{\mathrm{a}}$ & $0.64^{\mathrm{a}}$ & 0.53 & 0.16 \\
\hline Phe & $0.45^{\mathrm{b}}$ & $0.56^{\mathrm{b}}$ & $0.72^{\mathrm{a}}$ & $0.55^{\mathrm{b}}$ & 0.57 & 0.20 \\
\hline Thr & $0.84^{\mathrm{a}}$ & $0.88^{\mathrm{a}}$ & $0.91^{\mathrm{a}}$ & $0.62^{\mathrm{b}}$ & 0.81 & 0.19 \\
\hline Met & $0.29^{\mathrm{a}}$ & $0.41^{\mathrm{a}}$ & $0.42^{\mathrm{a}}$ & $0.11^{\mathrm{b}}$ & 0.31 & 0.24 \\
\hline Val & $0.49^{\mathrm{b}}$ & $0.36^{\mathrm{b}}$ & $0.80^{\mathrm{a}}$ & $0.78^{\mathrm{a}}$ & 0.61 & 0.28 \\
\hline \multicolumn{7}{|c|}{ Nonessential amino acids (\%) } \\
\hline Cys & $0.61^{\mathrm{a}}$ & $0.24^{\mathrm{b}}$ & $0.25^{\mathrm{b}}$ & $0.16^{\mathrm{b}}$ & 0.32 & 0.32 \\
\hline Tyr & 0.41 & 0.53 & 0.49 & 0.42 & 0.46 & 0.21 \\
\hline Asp & $1.05^{\mathrm{b}}$ & $1.23^{\mathrm{b}}$ & $1.73^{\mathrm{a}}$ & $0.56^{\mathrm{c}}$ & 1.14 & 0.76 \\
\hline Glu & $1.97^{\mathrm{b}}$ & $1.68^{\mathrm{b}}$ & $2.48^{\mathrm{a}}$ & $1.59^{\mathrm{b}}$ & 1.93 & 0.70 \\
\hline Ser & 0.68 & 0.59 & 0.62 & 0.71 & 0.65 & 0.18 \\
\hline Gly & $0.64^{\mathrm{b}}$ & $0.69^{\mathrm{b}}$ & $0.97^{\mathrm{a}}$ & $1.05^{\mathrm{a}}$ & 0.84 & 0.26 \\
\hline Ala & $0.32^{\mathrm{d}}$ & $0.59^{\mathrm{c}}$ & $0.86^{\mathrm{b}}$ & $1.04^{\mathrm{a}}$ & 0.70 & 0.37 \\
\hline Pro & $0.45^{\mathrm{c}}$ & $0.45^{\mathrm{c}}$ & $0.82^{b}$ & $1.00^{\mathrm{a}}$ & 0.68 & 0.31 \\
\hline Amino acids & $10.90^{\mathrm{b}}$ & $11.02^{\mathrm{b}}$ & $14.75^{\mathrm{a}}$ & $12.77^{\mathrm{b}}$ & 12.36 & 3.25 \\
\hline
\end{tabular}

${ }^{1}$ Each value is the mean of 18 samples by season.

abcd Values with different superscripts of the same row are significantly different $(p<0.05)$. 
고 겨울이 가장 낮은 결과를 보였다 $(\mathrm{p}<0.05)$. 조지방과 칼슘은 각각 봄과 가을이 가장 높았 다.

총 아미노산 함량을 보면 가을에 $14.75 \%$ 로 4 계절 중 가장 높았다 $(\mathrm{p}<0.05)$. 양돈사료에서 제 한아미노산이 되기 쉬운 라이신은 봄, 여름, 가 을 및 겨울에 각각 $0.49,0.41,0.69$ 및 $0.79 \%$ 로 가을과 겨울이 봄과 여름에 비해 유의적으로 높았다 $(\mathrm{p}<0.05)$. Methionine은 겨울에 $0.11 \%$ 로 타 계절보다 유의적으로 낮게 나타났다 $(\mathrm{p}<$ 0.05).

남은 음식물은 영양소 함량이 계절에 따라 다른 경향을 보이는데 이것은 다른 연구자들의 결과와 같은 경향이었다(이, 2000; Barth 등,
1966; Pond와 Maner, 1984; Ferris 등, 1995; Westendorf, 1996). 이와 같이 성분 함량에서 차이가 많이 나기 때문에 $\mathrm{FW}$ 를 사료로 이용하 기 위해서는 보다 많은 분석자료가 필요할 것 으로 사료되며, 일반원료를 가지고 배합하는 것과는 달리 정밀배합은 사실상 어려울 것으로 판단된다.

한편, 건조한 $\mathrm{FW}$ 의 미생물 함량을 살펴보면 Table 3 과 같다 (사료의 $\mathrm{TBC}, \mathrm{LAB}$ 및 대장균 군 박테리아). 먼저 총균수를 살펴보면 남은 음 식물, 단순건조, 발효사료순으로 점차 낮아짐을 알 수 있었으나 유의적인 차이는 없었다 $(\mathrm{p}>$ 0.05). 유산균 수는 단순건조와 진공발효에서는 차이가 없었으나 남은 음식물에서 유의적으로

Table 3. Microbial counts as affected by processing methods of food waste

\begin{tabular}{lcccc}
\hline & Food waste & Simple dry & Vacuum fermentation & SE \\
\hline \hline TBC $\left(10^{6}\right)$ & 36.67 & 2.33 & 0.50 & 20.37 \\
LAB $\left(10^{4}\right)$ & $369.50^{\mathrm{a}}$ & $54.67^{\mathrm{b}}$ & $3.50^{\mathrm{b}}$ & 198.20 \\
Coliform bacteria $\left(10^{2}\right)$ & 20.33 & N.D & 63.50 & 32.43 \\
\hline
\end{tabular}

ab Values with different superscripts of the same row are significantly differ $(\mathrm{p}<0.05)$. N.D : not detected. TBC : Total bacterial counts, LBA : Lactic acid bacterial counts, E-coli form : E-coli form bacteria.

Table 4. Effects of feeding food waste on the growth performance in finishing pigs

\begin{tabular}{ccccr}
\hline & Control & Simple dry & Vacuum fermentation & \multicolumn{1}{c}{ SE } \\
\hline \hline Phase I (0 4wk) & & & & \\
ADG (g) & $855^{\mathrm{a}}$ & $726^{\mathrm{b}}$ & $757^{\mathrm{ab}}$ & 79.82 \\
ADFI (g) & 2,326 & 2,035 & 2,201 & 307.74 \\
FCR & 2.72 & 2.84 & 2.91 & 0.42 \\
Phase II (4 8wk) & & & & \\
ADG (g) & 914 & 834 & 865 & 57.40 \\
ADFI (g) & 2,750 & 2,773 & 2,795 & 189.84 \\
FCR & 3.04 & 3.34 & 3.24 & 0.38 \\
Overall (0 8wk) & $884^{\mathrm{a}}$ & $780^{\mathrm{b}}$ & $811^{\mathrm{b}}$ & 54.88 \\
ADG (g) & 2,538 & 2,404 & 2,498 & 172.39 \\
ADFI (g) & 2.88 & 3.09 & 3.07 & 0.24 \\
FCR & (g) & & & \\
\hline
\end{tabular}

${ }^{\mathrm{ab}}$ Values with different superscripts of the same row are significantly differ $(\mathrm{p}<0.05)$. 
높게 나타났으며 $(\mathrm{p}<0.05)$ 대장균군 박테리아의 수는 단순건조 사료에서 검출되지 않았으나 각 각의 처리에서 유의적인 차이는 없었다 $(\mathrm{p}>$ 0.05). 이러한 결과는 건조와 발효의 방법차이 로서 열풍건조과정에서 많은 미생물이 사멸하 였으며 대장균 군도 $10^{2}$ 수준에서 검출되지 않 았으나, 진공발효과정에서 대장균군이 검출된 것은 새로운 원료 (일반 사료원료)내에 포함된 균이 $60 \sim 70^{\circ} \mathrm{C}$ 에서는 완전 사멸이 되지 않은 것으로 판단된다 (Lovell, 1990). 또한 진공발효 과정에서는 유산균의 수가 적은 것으로 보아 증식은 일어나지 않은 것으로 판단된다.

\section{2. 사양성적, 소화율 및 육질평가}

Table 4는 사양시험에 대한 결과이다. 비육전 기 $(50 \sim 85 \mathrm{~kg})$ 의 사양성적을 살펴보면, $\mathrm{ADG}$ 는 $\mathrm{SD}$ 의 경우 대조구에 비해 유의적으로 낮았으 나 $(\mathrm{p}<0.05), \mathrm{FD}$ 는 대조구와 차이가 없었다. 그 러나 $\mathrm{ADFI}$ 와 $\mathrm{FCR}$ 은 전처리간에 유의적인 차 이가 없었다. 비육후기에서도 $\mathrm{ADG}, \mathrm{ADFI}$ 및 $\mathrm{FCR}$ 에서 전처리간에 차이가 없었으나 대조구
가 $\mathrm{FW}$ 이 첨가된 사료에 비해 $\mathrm{ADG}$ 나 $\mathrm{FCR}$ 이 우수한 경향을 보였다. 전 기간의 사양성적에 서는 $\mathrm{ADG}$ 에서 대조구가 $\mathrm{FW}$ 이 첨가된 사료에 비해 유의적으로 높았으나 $(\mathrm{p}<0.05), \mathrm{ADFI}$ 와 $\mathrm{FCR}$ 에서는 처리간에 차이가 없었다.

이러한 결과는 건조한 남은 음식물을 사료에 $20 \%$ 를 사용할 때 비육전기에서는 일반사료에 비해 사양성적에서 뒤지나 비육후기에서는 차 이가 없음을 보여주고 있는데, Chae 등 (2000) 이 육성비육돈에서 건조한 남은 음식물의 적정 첨가수준은 $20 \%$ 라고 한 점과 이 등 (2001)이 비육돈에서 건조한 남은 음식물의 적정첨가수 준은 $10 \%$ 정도라고 한 점을 미루어 보면 본 연구에서 사용된 것도 $20 \%$ 이내에서 검토되어 야 할 것으로 사료된다.

한편, $\mathrm{SD}$ 와 $\mathrm{FD}$ 간의 비교에서는 $\mathrm{FD}$ 가 $\mathrm{ADG}$ 에서 전 시험기간에서 $4 \%$ 정도 높은 것으로 나타났으나 통계적인 유의차는 인정되지 않았 으며, $\mathrm{ADFI}$ 및 $\mathrm{FCR}$ 에서도 차이가 없었다. Table 5에서 시험사료의 소화율을 제시하였는 데, 소화율에서 비육전기나 비육후기 공히 건 물, 에너지, 단백질 등에서 대조구에 비해 남은

Table 5. Nutrient digestibility of experimental diets in finishing pigs

\begin{tabular}{ccccc}
\hline & Control & Simple dry & Vacuum fermentation & SE \\
\hline \hline Phase I (0-4wk) & & & & \\
DM & $78.24^{\mathrm{a}}$ & $67.12^{\mathrm{b}}$ & $65.63^{\mathrm{b}}$ & 6.85 \\
GE & $80.55^{\mathrm{a}}$ & $70.01^{\mathrm{b}}$ & $68.78^{\mathrm{b}}$ & 6.40 \\
CP & $75.51^{\mathrm{a}}$ & $62.41^{\mathrm{b}}$ & $57.35^{\mathrm{b}}$ & 8.98 \\
Ca & $50.01^{\mathrm{a}}$ & $17.92^{\mathrm{b}}$ & $27.04^{\mathrm{b}}$ & 15.73 \\
P & 37.46 & 22.02 & 30.49 & 12.33 \\
\hline Phase II (4-8wk) & & & \\
DM & $74.37^{\mathrm{a}}$ & $68.44^{\mathrm{b}}$ & $72.47^{\mathrm{ab}}$ & 3.87 \\
GE & 77.06 & 72.23 & 75.30 & 3.45 \\
CP & 68.85 & 67.28 & 66.27 & 4.44 \\
Ca & $36.32^{\mathrm{a}}$ & $22.29^{\mathrm{b}}$ & $22.18^{\mathrm{b}}$ & 9.02 \\
P & $29.18^{\mathrm{ab}}$ & $18.86^{\mathrm{b}}$ & $33.40^{\mathrm{a}}$ & 9.07 \\
\hline
\end{tabular}

${ }^{a b}$ Values with different superscripts of the same row are significantly differ $(p<0.05)$. 
Table 6. Effects of feeding food waste on carcass traits in finishing pigs*

\begin{tabular}{lcccc}
\hline & Control & Simple dry & Vacuum fermentation & SE \\
\hline \hline Carcass trait & & & & \\
Dressing percentage & 75.18 & 75.47 & 73.89 & 2.69 \\
Backfat (10th rib, mm) & 25.00 & 26.00 & 24.33 & 3.02 \\
Loin eye area $\left(\mathrm{Cm}^{2}\right)$ & 60.99 & 62.40 & 63.86 & 7.99 \\
Fat free lean index (\%) & 53.24 & 51.21 & 52.14 & 2.07 \\
\hline Pork trait & & & & \\
Drip loss (\%) & & & & 1.28 \\
D 0 & 2.66 & 4.76 & 2.52 & 1.76 \\
D 5 & 8.91 & 10.83 & 8.31 & 1.45 \\
D 10 & 11.56 & 12.65 & 11.78 & \\
TBARS (mg/kg) & & & & 0.21 \\
D 0 & 0.93 & 0.94 & 0.73 & 0.47 \\
D 5 & 1.47 & 1.56 & 1.91 & 1.48 \\
D 10 & 2.40 & 2.83 & 2.63 & 0.17 \\
Pork color & 1.83 & 2.00 & 2.00 & 0.53 \\
Marbling score & 1.83 & 1.33 & 1.50 & \\
\hline
\end{tabular}

* Not significant $(\mathrm{p}>0.05)$.

${ }^{1}$ NPPC (1991).

Table 7. Feed cost per kg gain in pigs fed food waste

\begin{tabular}{lcccc}
\hline & Control & Simple dry & Vacuum fermentation & SE \\
\hline \hline Phase I (0-4wk) & & & & \\
Feed cost (W/kg) & 196.01 & 162.75 & 162.75 & - \\
Total weight gain (kg/head) & $23.94^{\mathrm{a}}$ & $20.33^{\mathrm{b}}$ & $21.20^{\mathrm{ab}}$ & 2.24 \\
Total feed intake (kg/head) & 65.13 & 56.98 & 61.63 & 8.62 \\
Feed cost/weight gain (W/kg) & 533.24 & 456.20 & 473.21 & 76.64 \\
\hline Phase II (4-8wk) & & & & \\
Feed cost (W/kg) & 180.70 & 151.49 & 151.49 & 1.61 \\
Total weight gain (kg/head) & 25.59 & 23.35 & 24.22 & 5.32 \\
Total feed intake (kg/head) & 77.00 & 77.64 & 78.26 & 64.71 \\
Feed cost/weight gain (W/kg) & 543.68 & 503.70 & 489.50 & \\
\hline Overall (0-8wk) & & & & 3.09 \\
Total weight gain (kg/head) & $49.53^{\mathrm{a}}$ & $43.68^{\mathrm{b}}$ & $45.42^{\mathrm{b}}$ & 10.37 \\
Total feed intake (kg/head) & 142.13 & 134.62 & 139.89 & 49.86 \\
Feed cost/weight gain (\#/kg) & 538.63 & 481.59 & 481.90 &
\end{tabular}

${ }^{a b}$ Values with different superscripts of the same row are significantly differ $(p<0.05)$. 
음식물이 포함된 사료가 낮았다. $\mathrm{SD}$ 와 $\mathrm{FD}$ 사이 에도 영양소 소화율에서는 차이가 없었다. 이 것은 남은 음식물을 발효시켜도 소화율에 큰 차이가 없음을 의미한다.

Table 6은 도체 및 육질에 대한 분석결과이 다. 먼저 도체성적을 살펴보면, 지육율, 등지방 두께, 배장근 단면적 그리고 무지방살코기율은 처리에 따른 유의적인 차이가 없었다 $(\mathrm{p}>0.05)$. 그리고 육색, 마블링, 보수력 및 산패도 (TBARS)에 있어서도 처리간에 유의적인 차이 가 없었다. 이와 같은 결과는 다른 연구에서 발표된 것과 유사한 것으로 (Bryhni 등, 1999; Myer 등, 1999; Chae 등, 2000) 육성비육돈에서 남은 음식물 $20 \%$ 를 사용할 때 육질에는 별 영 향이 없음을 의미한다.

\section{3. 경제성 분석}

Table 7은 시험사료의 $\mathrm{kg}$ 단가와 $\mathrm{kg}$ 증체시 사료비용을 각 단계별로 제시한 것이다. 여기 서 사료비 계산시 남은 음식물의 가공비용은 톤당 26,132 원, 발효 건조시는 28,399 원이였으 나 사료비에서 원재료비로는 포함시키지 않았 다. 왜냐하면, 남은 음식물을 사료화할 경우 지 방자치단체에서 보조해 주기 때문이다. 즉, 남 은 음식물을 매립하거나 소각, 또는 퇴비화할 경우 처리비용이 들어가기 때문에 그 비용으로 사료로 활용시 처리비용이 되기 때문이다.

전 시험기간의 증체 $\mathrm{kg}$ 당 사료비를 살펴보 면, 대조구는 538.63원, $\mathrm{SD}$ 는 481.59원, 그리고 $\mathrm{FD}$ 는 481.90 원으로서 남은 음식물을 $20 \%$ 사용 할 경우 증체 $\mathrm{kg}$ 당 사료비를 57 원 정도 줄일 수 있을 것으로 사료된다.

\section{IV. 요 약}

본 연구는 남은 음식물 $(\mathrm{FW})$ 의 성분변이를 조사하고, 그것의 급여시 비육돈의 성장과 육 질에 미치는 영향을 조사하기 위하여 실시하였
다. 사료화를 위해 기초자료로 활용하고져 $\mathrm{FW}$ 를 1년간 (월 6 회) 수집하였다. 8 주간의 사양시 험을 위해 삼원교잡종 $(\mathrm{L} \times \mathrm{Y} \times \mathrm{D})$ 비육돈 $(54.80 \pm$ $4.60 \mathrm{~kg}$ ) 117 두를 공시하였다 (3처리 3반복, 반 복당 13두). 처리는 대조구 (옥수수-대두박 위 주사료), 건조 방법에 따른 단순 건조 (simple dry: SD) 및 진공발효 (vacuum fermentation: $\mathrm{VF}$ )로서 구분하였다.

$\mathrm{FW}$ 의 건물기준으로 에너지, 조단백질, 조지 방, 회분, 칼슘 및 인의 4 계절 평균치는 각각 $5,111 \mathrm{kcal} / \mathrm{kg}, 22.92 \%, 14.31 \%, 15.48 \%, 2.7 \%$ 및 $1.05 \%$ 였다. 에너지와 단백질 함량은 각각 겨울 과 여름에 가장 높았다 $(\mathrm{p}<0.05)$. 건조한 $\mathrm{FW}$ 의 유산균 함량은 $\mathrm{SD}$ 와 $\mathrm{VF}$ 처리간에 차이가 없었 다. 사양성적에서는 $\mathrm{ADG}$ 에서 대조구가 $\mathrm{FW}$ 이 첨가된 사료에 비해 유의적으로 높았으나 ( $\mathrm{p}<$ $0.05), \mathrm{FCR}$ 에서는 처리간에 차이가 없었다. $\mathrm{SD}$ 와 $\mathrm{FD}$ 와의 생산성 비교에서는 유의차가 인정 되지 않았다. 지육율, 등지방두께, 그리고 기타 육질 (색깔, drip loss 및 TBARS)에서 처리간에 차이가 없었다. 전 시험기간의 증체 $\mathrm{kg}$ 당 사료 비를 살펴보면, $\mathrm{FW}$ 가 포함된 사료급여군이 대 조구에 비해 낮았다.

이상의 결과를 요약해 보면, 남은 음식물을 건조한 후 사료에 $20 \%$ 이내를 첨가하여 펠렛 사료로 급여할 경우 비육돈의 사료비를 절감할 수 있을 것으로 사료된다. 그러나 $\mathrm{FW}$ 의 가공 시 $\mathrm{FD}$ 공정은 필요치 않을 것으로 사료된다.

(색인 : 단순건조 및 진공발효건조 남은 음식물, 성장, 육질, 돼지)

\section{V. 감사의 글}

본 연구는 원주소재 진들농산, 강원대 산학 연 컨소시움 센터 및 강원지역 환경기술개발센 터에서 부분적인 연구비를 지원하여 수행하게 되었으므로 이들 업체 및 기관에 감사 드립니 다. 


\section{VI. 인 용 문 헌}

1. AOAC. 1990. Offcial methods of analysis. 15th ed. Association of Official Analytical Chemists. Washington. D.C.

2. Barth, K. M., Vander Noot, G. W., MacGrath W. S. and Kornegay, E. T. 1966. Nutritive value of garage as a feed for swine. П. Mineral content and supplementation. J. Anim. Sci. 25:52.

3. Bryhni, E. A., Kjos, N. P., Overland, M. and Sorheim, O. 1999. Food waste products in diets for growing-finishing pigs: Effect on growth performance, carcass characteristics and meat quality. 45th Intl. Congress of Meat Sci. and Tech. Aug. 1-6. Yokohama, Japan. 1:82.

4. Chae, B. J., Choi, S. C., Kim, Y. G., Kim C. H. and Sohn, K. S. 2000. Effects of Feeding Dried Food Waste on Growth and Nutrient Digestibility in Growing-Finishing Pigs. Asian-Aus. J. Anim. Sci. 13:1304.

5. Ferris, D. A., Flores, R. A., Shanklin, C. W. and Whitrworth, M. K. 1995. Proximate analysis of food service wastes. Applied Engineering in Agriculture. 4:567.

6. Kim, Y. H., Kim, I. S. and Lee. M. 1997. The quality comparison of frozen porks exported to japanese market from different countries. Korean J. Anim. Sci. 39(6):715.

7. Lovell, H. R. 1990. The microbiology of dried milk powders. In: Dairy microbiology (Vol. 1, 2nd ed.) (Edited by Robinson R. K.). Elsevier Applied Science. London and New York. p. 245270.

8. Myer, R. O., Brendemuhl J. H. and Johnson. D. D. 1999. Evaluation of dehydrated food waste product as feedstuffs for finishing pigs. J. Anim. Sci. 77:685.

9. NPPC. 1991. Procedures to Evaluate Market Hogs (3rd ed,). National Pork Producers Council. Des Moines. IA.

10. Pond, W. G. and Maner, J. H. 1984. Swine production and nutrition. AVI Publishing Co. Westport, CT. p. 336.

11. SAS. 1985. SAS. User's Guide : Statistics, SAS Inst. Inc. Cary. NC.

12. Sinnhuber, R. O. and Yu, T. C. 1977. The 2-thiobarbituric acid reaction, an objective measure of the oxidative determination occurring in fats and oils. J. Jap. Soc. Fish Sci. 26:259.

13. Snedecor, G. W. and Cochran, W. G. 1980. Statistical Methods (7th ed.). Iowa Stste University Press. Ames, IA.

14. Westendorf, M. L., Zirkel, E. W. and Gordon, R. 1996. Feeding food or table waste to livestock. Prod. Anim. Sci. 12:129.

15. 문종상. 2001. 습식발효 남은 음식물의 급여가 육성비육돈의 성장, 영양소 소화율 및 육질에 미 치는 영향. 석사학위논문. 강원대학교. 춘천.

16. 오상집. 2001. 남은 음식물 사료화 시설의 개선 방향. 남은 음식물 안전사료화 기술자료집. 축산 기술연구소. 수원. p. 71.

17. 유기영. 2001. 남은 음식물 사료화의 경제성 효 과분석. 남은 음식물 안전사료화 기술자료집. 축 산기술연구소. 수원. p. 115.

18. 이명희, 박종석, 김종오. 1998. 잔여음식물쓰레기 관리의 광역적 최적화방법. 한국유기성폐자원학 회, 가을학술대회. p. 53.

19. 이병석, 정광화, 정완태, 조성백, 정일병. 2001. 남은 음식물의 안전한 사료화 방안. 남은 음식물 안전사료화 기술자료집. 축산기술연구소. 수원. p. 89.

20. 이상곤. 2000. 남은 음식물 사료의 사료가치에 관한 연구. 석사학위논문. 강원대학교. 춘천.

21. 한인규, 이영철, 정근기, 김영길, 안병홍, 명규호, 고태송. 1987. 영양학 실험법. 동명사.

(접수일자 : 2003. 1. 22 / 채택일자 : 2003. 4. 29) 